P-ISSN: 2774-4574; E-ISSN: 2774-4582 TRILOGI, 1(2), Sept - Des 2020 (46-55) @2020 Lembaga Penerbitan, Penelitian, dan Pengabdian kepada Masyarakat (LP3M) Universitas Nurul Jadid Paiton Probolinggo DOI: https://doi.org/

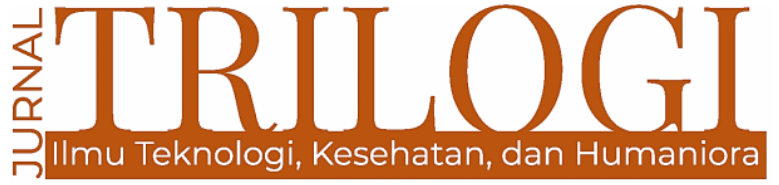

\title{
INTEGRASI INTERKONEKSI PENDIDIKAN MULTIKULTURAL BERBASIS MODERASI ISLAM MELALUI KURIKULUM KEAGAMAAN PENDIDIKAN TINGGI
}

\author{
Khalid Al-Madani
}

Sekolah Tinggi Agama Islam Istiqlal, Buleleng, Bali

elmadanibocahangon@gmail.com

\begin{abstract}
Due to the recent issues of social communication in multicultural and plural state such as Indonesia, a systematic formulation of curriculum at Islamic higher educations in terms of integration and interconnection of Islamic modaration based multicultural education, is necessary. This study is to portray the possible ways of integration and interconnection of Islamic moderation based multicultural at higher education, of curriculum of religious multicultural education at higher education, and of implementation of this strategy of integration and interconnection.
\end{abstract}

Keywords: integration interconnection, multicultural education, religious education, curriculum of higher education

\begin{abstract}
Abstrak
Untuk mengurai kejumudan komunikasi sosial dalam kehidupan masyarakat yang plural dan multikultural seperti Indonesia, formulasi kurikulum pendidikan tinggi yang lebih konkrit dan sitematis, yaitu integrasi interkoneksi pendidikan multikultural berbasis moderasi Islam melalui pendidikan tinggi, menjadi sangat penting dilakukan. Tulisan ini berusaha menjelaskan bagaimana integrasi interkoneksi pendidikan multikultural berbasis moderasi Islam di perguruan tinggi, kurikulum keagamaan pedidikan multikultural berbasis moderasi islam di perguruan tinggi, dan implementasi integrasi interkoneksi pendidikan multikultural berbasis moderasi islam di perguruan tinggi.
\end{abstract}

Katakunci: integrasi interkoneksi, pendidikan multikultural, moderasi agama, kurikulum pendidikan tinggi 


\section{Pendahuluan}

Kekerasan dan kejahatan yang muncul dari isu-isu radikalisme, ekstremisme, liberalism, terorisme dan apapun nama lainnya, merupakan musuh bagi semua agama. Kendatipun, semua faham tersebut 'dikaitkan' dan atau kemunculannya selalu bersinggungan dengan urusan agama (Yunus, 2017). Karena itu banyak tokoh bangsa lintas agama yang mengambil peran menawarkan solusi untuk mengatasi konflik horizontal tersebut dengan jalan tengah (dialog antar agama) yang didasarkan pada komitmen bersama untuk mengembangkan kesejahteraan manusia. Hal ini tidak lain karena agama-agama di dunia ini tanpa terkecuali memiliki tanggung-jawab global untuk menciptakan kerukunan dan merawat bumi (Knitter \& Paul, 2008).

Doktrin atau ajaran Islam memiliki rangkaian yang cukup panjang dalam mengatur semua aspek kehidupan manusia. Hanya saja, disayangkan terkadang pemahaman terhadap Islam tidak dipahami secara utuh, melainkan pemahaman secara parsial (tidak komprehensif), sehingga terbawa dalam perilaku kehidupan seharihari. Diantara mereka ada yang inklusif dalam memahami agama, sebagian lain memahami secara ekslusif, dan atau bahkan memiliki pemahaman yang ekstrem. Sehingga memunculkan sikap ekstrem (ekstremisme) atau radikal (radikalisme).

Pemahaman ektrem dan radikal barangkali terlalu berlebihan bila dikontektualkan dalam fakta bangsa Indonesia. Mengapa demikian? Karena bila ditinjau dari perspektif antropologi, Indonesia sebagai negara yang pluralistik dengan keberagaman agama, etnis, seni, tradisi, dan cara/pola hidup dengan ciri dan kekhasan masing-masing tanpa menghilangkan makna kesatuan Indonesia sebagai bangsa yang besar (Nasaruddin, 2014).

Radikalisme, menurut Amrullah (2018), sering disertai dengan sikap ekstrem seperti kekerasan, paksaan, dan teror terhadap kelompok-kelompok yang dianggap bertentangan dengan ideologi mereka. Secara historis, Islam juga telah melahirkan orang-orang yang tidak proporsional dalam agama sehingga mereka dapat disebut sebagai tokoh dan kelompok radikal dalam Islam. Jejak radikalisme dalam Islam, menurutnya dapat ditelusuri keberadaannya bahkan dimulai dari awal pembentukan Islam yaitu masa dakwah Nabi Muhammad SAW. Sikap ekstrem ini kemudian terus hidup dan berkembang dan bahkan membangun keberadaannya dengan membentuk kelompok tertentu. Ironisnya, kelompok radikal yang mengejar pemurnian Islam ini masih hidup dan berkembang hingga hari ini" (Amrullah, 2018).

Kemunculannya dan perkembangannya telah merambah ke Indonesia, disebabkan factor perkembangan global, penyebaran paham wahabisme dan juga kemiskinan. Faham radikalisme di Indonesia terpengaruh dari negara-negara Timur Tengah; Afganistan, Palestina, Irak, Yaman, Mesir, Syiria, dan Turki, yang sangat kental dengan agenda-agenda politik. Tidak demikian halnya dengan kemuculan Radikalisme di Indonesia sejak awal abad ke-20. Gerakan radikal Islam di Indonesia baru sebatas pada tuntutan dipenuhinya aspirasi Islam (Syariat Islam/Piagam Jakarta (Ahmad \& Ansori, 2015).

Penyebab menguatnya radikalismeekstremisme menurut Haidar Bagir sedikitnya disebabkan karena dua faktor penting, yaitu faktor dokrinal historis dan faktor sosial-politik (Haidar, 2017). Amrullah menguraikannya bahwa faktor dokrinal histroris dapat di lacak berakar dari cara pandang terhadap agama yang menekankan pada aspek-aspek yang kaku dalam hukumhukum keagamaan. Sebagai akibatnya, menurutnya, berkembanglah sikap eksklusif, bahkan muncul rasa keharusan untuk menghukum orang yang dianggap membangkang terhadap ajaran Tuhan (kafir).

Sementara itu, faktor sosial-politik tampak dalam peristiwa international 'perang dingin' antara Sunni Arab Saudi dan Syi'ah Iran. Saudi di satu pihak memosisikan diri sebagai pelingung kaum sunni.Teheran secara alami bersekutu dengan komunitas syi'ah yang hidup di Lebanon, Irak dan lainnya. Faktor inilah yang menurut Bagir menjadi penyebab menguatnya RadikalismeEkstremisme. 


\section{Metode}

Penelitian ini menggunakan pendekatan kualitatif, yaitu mendeskripsikan dan menguraikan tentang pengaruh penggunaan media pembelajaran dalam dunia pendidikan. Teknik pengumpulan data yang digunakan dalam penelitian ini adalah studi kepustakaan (Library Research) dimana studi kepustakaan adalah kegiatan mengumpulkan bahanbahan yang berkaitan dengan penelitian yang berasal dari buku, jurnal-jurnal ilmiah, literatur-literatur dan publikasi-publikasi lain yang layak dijadikan sumber untuk penelitian yang akan di teliti penulis, dengan cara mendeskripsikan dan menguraikan data tersebut adalah melalui beberapa pendapat para ahli. Variabel penelitian adalah segala sesuatu yang berbentuk apa saja yang ditetapkan oleh peneliti untuk dipelajari sehingga diperoleh informasi tentang hal tersebut kemudian ditarik kesimpulannya. Variabel yang digunakan dalam penelitian adalah Variabel Bebas (Independent Variable) dan Variabel Terikat (Dependent Variable). Maka dengan menggunakan pendekatan kualitatif penelitian ini diharapkan bisa memberikan fakta-fakta secara komprehensif tentang pengaruh penggunaan media pembelajaran dalam dunia pendidikan. Manfaat dari penulisan ini adalah untuk menambah wawasan bagi para pembaca mengenai pentingnya media pembelajaran dalam dunia pendidikan.

\section{Hasil dan Pembahasan}

\subsection{Pendidikan Multikultural}

Pendidikan multikultural merupakan wacana yang terus menarik untuk di kaji di tengah merebaknya ideologi, paham atau aliran yang mengikis keharmonisan warga, nasionalisme dan kebhinnekaan Negara Kesatuan Republik Indonesia. Banyaknya peristiwa-peristiwa yang memicu konflik di tengah kehidupan masyarakat pemicunya antara lain adalah persoalan SARA. Unsurunsur tersebut dalam kehidupan bermasyarakat terkadang mengalami proses kebersinggungan yang mengarah kepada ketidakharmonisan. Misalnya, minoritas yang termarjinalkan, pada masa Gurdur mendapatkan perhatian khusus; persoalan aliran Ahmadiyah yang mendapatkan pembelaan.

Perbedaan budaya merupakan sebuah keniscayaan, yang menjadi bagian dalam kehidupan dan patut diperhatikan sebagai proses membangun dan mewujudkan tujuan dalam maksud kehadiran sebuah agama. Di mana pada dasarnya, setiap agama memiliki karakteristik tersendiri dalam konsep keadilan, kedamaian, keharmonisan, dan seterusnya. Hubungan agama dan negara hingga saat ini masih terus relevan untuk diuraikan. Agama mengajarkan kepada pemeluknya untuk mencapai kemulian hidup melalui interaksi sosial yang berkualitas. Dalam konteks beragama setiap individu memiliki kesempatan yang sama dalam memilih dan mengamalkan ajaran agamanya (kebebasan beragama). Hal ini di dasarkan pada Firman Allah SWT. Dalam Al-Quran dalam Qs Al-Kafirun, 1-6:

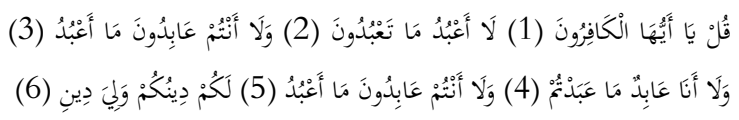

Artinya: "Katakanlah Hai Muhammad SAW: "Hai orang-orang yang kafir." Aku tidak menyembah apa yang kau sembah. Dan kamu bukan penyembah Tuhan yang aku sembah. Dan aku tidak pernah menjadi penyembah apa yang kamu sembah. Dan kamu tidak pernah pula menjadi penyembah Tuhan yang aku sembah. Untukmulah agamamu dan untukkulah agamaku."

Dari ayat di atas jelas interaksi sosial tetap bisa dilakukan dengan sesama manusia dengan mengedepankan sikap toleran dan moderat dalam memahami agama. Sedang yang tidak diperkenankan sekaligus pembeda berkaitan dengan ranah keyakinan. Dalam konteks kebebasan beragama, Abdurrahman Wahid (Gus Dur) tidak mengatakan bahwa setiap agama sama dalam ajaran (akidah tauhid). Namun ajaran setiap agama justru memiliki perbedaan, tetapi tidak perlu dipertentangkan karena pertentangan adalah sebuah malapetaka. Karena itu, perpedaan bukanlah alasan menebarkan benih konflik dan perpecahan (Wahid, 2006).

Konsep kebebasan beragama dalam pandangan Abdurrahman Wahid tersebut dalam Damrizal (2016) ditawarkan sebagai sebuah kesadaran adanya keberagaman kaum muslim dan keragaman manusia. 
Dimana umat beragama dapat berdampingan dengan rukun tanpa ada diskriminasi dari pihak mana pun. Masing-masing individu memiliki kesempatan dan hak yang sama menunjukkan identitas dalam semua aspek kehidupan (Damrizal, 2016). Pendidikan multikultural menjadi penting untuk diajarkan kepada peserta didik karena paradigma generasi masa depan perlu dipupuk sejak dini agar mampu menjadi manusia Indonesia seutuhnya, sebagai pemimpin dimuka bumi (kholifah fi al-ard) 'memanusiakan manusia dan alam sekitarnya'.

Adapun perbedaan dalam keragaman merupakan kehendak Allah SWT agar kita saling mengenal, memahami dan bertoleranensi dengan segala jenis perbedaan, sebagaimana Firman-Nya dalam Qs. Al-Hujurat 13:

$$
\begin{aligned}
& \text { يا أيها الناس إنا خلقناكم من ذكر وأننى وجعلناكم شعوبا وقبائل لتعارفوا، } \\
& \text { إن أكرمكم عند الله أتقاكم، إن الله عليم خبير (الحجرات: 13). }
\end{aligned}
$$

Artinya: "Hai manusia, Sesungguhnya Kami telah menciptakan kamu dari seorang laki-laki dan seorang perempuan, kemudian kami jadikan kamu berbangsa-bangsa dan bersuku-suku supaya kamu saling mengenal. Sesungguhnya, yang paling mulia diantara kamu disisi Allah ialah orang yang paling taqwa diantara kamu. Sungguh Allah Maha mengetahui."

Berdasarkan paparan ayat di atas, dapat dipahami dengan pemikiran inklusif (tidak merasa paling benar) dalam konteks sosial kemasyarakatan yang plural dan majmuk seperti Indonesia, Islam harus tampil dengan wajah ramah dan peduli terhadap "persamaan derajat" dalam segala aspek kehidupan manusia. Dalam ayat ini pula dijelaskan bahwa kemuliaan hidup bisa didapat melalui pengembangan sikap sosial terhadap siapapun atas dasar taqwa. Dengan kata lain, kemampuan berkomuikasi, interaksi dan bertoleransi dalam perbedaan identitas akan mengantarkan kita menjadi manusia yang berkualitas unggul secara pribadi maupun sosial.

Ini sesuai dengan risalah Islam (kedamaian) yang bawa nabi Muhammad saw, beliau memberikan teladan kepemimpinan ideal pada kesepakatan "Piagam Madinah", dimana pesan utama yang dibawa adalah "persamaan hak" ( مساواة (الحقوق antar suku yang beragam masa itu. Pesan yang dapat kita ambil dari refleksi "piagam madinah" yang dicontohkan nabi adalah pengembangan sikap toleran kepada sesama manusia dalam konteks kehidupan di tengah masayarakat yang heterogen (Musa, 2014).

Adalah Gusdur sebagai Bapak Bangsa yang mengajarkan toleransi dalam kata dan sikap konkrit, dirinya tampil sebagai sosok utama dalam moderasi berfikir dan moderat dalam beragama, baginya agama Islam harus tampil sebagai pemersatu bangsa, menjadi pelindung keragamaan, dan mampu menjawab tantangan modernitas. Islam tidak perlu membawa embel-embel dalam mewarnai kehidupan berbangsa dan bernegara dalam kontek kenusantaraan. Dalam format pendidikan multikultural menurut Azra dalam Sangadji setidaknya memiliki empat makna atau model yaitu; a) pengajaran tentang keragaman budaya sebagai sebuah pendekatan asimilasi kultural, b) pengajaran tentang berbagai pendekatan dalam tata hubungan sosial, c) pengajaran untuk memajukan pluralisme tanpa membedakan strata sosial dalam masyarakat, dan d) pengajaran tentang refleksi keragaman untuk meningkatkan pluralisme dan kesamaan. Azra menambahkan bahwa pendidikan multikultural dipahami sebagai pendidikan utuh tentang kebudayaan dalam merespon perubahan dan kultural lingkungan masyarakat tertentu atau bahkan dunia secara global (Kapraja, 2016).

Menurut Manachem Ali, Indonesia memiliki dua pilar utama; a) keagamaan b) kebangsaan, dua pilar ini harus dirawat dengan baik. Apabila salah satu dari keduanya roboh, Indonesia sebagai sebuah bangsa juga akan roboh pula. Menachem menilai bahwa konflik dan intoleransi agama di Indonesia terjadi karena kurangnya dialog dan kajian lintas agama yang membahas isiisi dalam ajaran dan kitab agama. Penolakan atas nilai-nilai agama tertentu yang selama ini ramai diperbincangkan oleh masyarakat pada dasarnya hanyalah asumsi tanpa dasar yang lahir dari pemahaman yang minim terhadap agama itu sendiri.

Dan pada tanggal 16 November 1996 dideklarasikan Hari Toleransi Internasional dengan tujuan menumbuhkan nilai dan sikap 
toleransi dalam kehidupan di muka Bumi ini. Karena hanya dengan mengajarkan toleransi dalam kehidupan, kerukunan umat manusia khususnya di Indonesia dapat dibangun. Terdapat tiga cara yang bisa dilakukan dalam merawat toleransi di Indonesia, yaitu: 1). Pendidikan Ketidaktahuan tentang perbedaan budaya, agama dan etnis yang ada di sekitar dapat menyebabkan ketidakamanan. Dengan pendidikan, diharapkan adanya pemahaman yang lebih baik tentang tradisi dan keyakinan yang berbeda dan penerimaan yang lebih besar dari mereka. 2). Regulasi dan Penegakkan Hukum Perlu adanya UU yang menindak tegas tindakan-tindakan intoleransi seperti ujaran kebencian, diskriminasi, SARA. Serta adanya penegakkan hukum dan peradilan yang menjamin hak-hak para korban intoleransi. 3). Hentikan Stereotip Negatif Orang yang memiliki stereotip negatif biasanya memiliki prasangka buruk terhadap seseorang atau kelompok yang mendapat 'label' negatif tersebut. Jadi, orang atau kelompok yang memiliki stereotip negatif didorong tidak menghakimi orang lain dengan cara generalisasi.

\subsection{Integrasi Interkoneksi Ilmu}

Upaya integrasi ilmu pengetahuan dalam Islam terus dilakukan oleh para ilmuwan muslim seperti Fazlur Rahman, Seyyed Hossein Nasr, Ziauddin Sardar, Ismail Raji al-Faruqi, dan Syekh Muhammad Naquib alAttas. Di Indonesia upaya integrasi ilmu juga terus dikembangkan oleh para ilmuwan dan akademisi, seperti Kuntowijoyo dengan konsep "Pengilmuan Islam" dalam judul karya bukunya "Islam sebagai IImu; Epistemologi, Metodologi, dan Estetika, terbitan tahun 2004. Dijelaskan bahwa Al Qur'an sebagai paradigma dilakukan dengan cara integralisasi dan objektifikasi. Integralisasi yaitu pengintegrasian kekayaan keilmuan manusia dengan wahyu. Sedangkan objektifikasi yaitu menjadikan pengilmuan Islam sebagai rahmat untuk semua orang (Imam, 2015).

Selain Kuntowijoyo, ilmuwan yang mampu menjelaskan pengklasifikasian ilmu pengetahuan baru, menurut Izudin ada Mulyadi Kartanegara dalam karyanya "Integrasi IImu: Sebuah Rekonstruksi Holistik" tahun 2005, membahas mengenai pembidangan ilmu pengetahuan berdasarkan rumpunnya dengan penekanan pada pengintegrasian ilmu pengetahuan, yang menegasikan dikotomi ilmu-ilmu agama dan ilmu-ilmu umum. Menurutnya, apa yang telah dilakukan oleh para ilmuan Muslim pada masa klasik dan pertengahan mengenai klasifikasi ilmu pengetahuan, seperti yang dilakukan al-Ghazali, bukan merupakan pendikotomian ilmu pengetahuan umum dan agama atau sebaliknya. Melainkan ia merupakan suatu bentuk pemilahan terhadap disiplin keilmuan berdasarkan cakupan dan kandungannya (Izudin, 2017).

Interkoneksi menurut Amin Abdullah dalam Machali adalah usaha memahami kompleksitas fenomena kehidupan yang dihadapi dan dijalani manusia, setiap bangunan keilmuan apapun, baik keilmuan agama (termasuk agama Islam, dan agamaagama lain) keilmuan sosial, humaniora, maupun kealaman tidak dapat berdiri sendiri tanpa kerjasama, saling tegur sapa, saling membutuhkan, saling koreksi, dan saling berhubungan antardisiplin keilmuan. Pendekatan integratif-interkonektif adalah pendekatan yang berusaha saling menghargai; keilmuan umum dan agama sadar akan keterbatasan masing-masing dalam memecahkan persoalan manusia, hal ini akan melahirkan sebuah kerja sama setidaknya saling memahami pendekatan (approach) dan metode berpikir (process and procedure) antara kedua kelimuan tersebut (Imam, 2015). Secara substansial paradigma integrasi interkoneksi, menurut Amin Abdullah adalah mengonsepsikan hubunganhubungan aneka macam keilmuan, antara ilmu-ilmu keislaman dan ilmu-ilmu umum, dalam simbolisasi jaring laba-laba.

Hakikatnya, pengembangan ilmu pengetahuan agama dan sains tidak perlu didikotomikan, karena keduanya merupakan satu kesatuan yang saling melengkapi. IImuilmu agama (keagamaan) sarat dengan muatan teologis, dan bersifat deduktif betapapun sistematisnya, ilmu tetap bersumber dari wahyu, dan tidak semuanya bersifat empirik. Sedangkan dalam keilmuan sains bersumber dari pengalaman empiris dan bersifat induktif. Keduanya harus dipadukan secara seimbang dan nin dikotomik (Hidayat, 2014).

Integrasi keilmuan alam misalnya, dalam pembelajaran Pendidikan AgamaIislam, dicontohkan Assegaf bisa 
diintegrasikan dalam lima tingkat, yaitu; Integrasi tingkat filosofis, integrasi tingkat metode dan pendekatan riset, integrasi tingkat materi, integrasi tingkat strategi, dan integrasi tingkat evaluasi. Kelima tingkat tersebut menurut Hidayat harus dilakukan secara simultan dan sinergis agar tiap level mengalami keterpaduan (Hidayat, 2014). Hidayat menyatakan bahwa perbincangan dan pengembangan integrasi keilmuan islam semakin genjar dilakukan. Transformasi perguruan tinggi STAIN dan atau IAIN menjadi Universitas Islam negeri (UIN) menunjukkan pembingkaian intergrasi interkoneksi keilmuan.

Upaya integrasi ilmu pengetahuan dalam Islam terus dilakukan oleh para ilmuwan muslim seperti Fazlur Rahman, Seyyed Hossein Nasr, Ziauddin Sardar, Ismail Raji al-Faruqi, dan Syekh Muhammad Naquib alAttas. Di Indonesia upaya integrasi ilmu juga terus dikembangkan oleh para ilmuwan dan akademisi, seperti Kuntowijoyo dengan konsep "Pengilmuan Islam" dalam judul karya bukunya "Islam sebagai Ilmu; Epistemologi, Metodologi, dan Estetika, terbitan tahun 2004. Dijelaskan bahwa Al Qur'an sebagai paradigma dilakukan dengan cara integralisasi dan objektifikasi. Integralisasi yaitu pengintegrasian kekayaan keilmuan manusia dengan wahyu. Sedangkan objektifikasi yaitu menjadikan pengilmuan Islam sebagai rahmat untuk semua orang.

Selain Kuntowijoyo, ilmuwan yang mampu menjelaskan pengklasifikasian ilmu pengetahuan baru, menurut Izudin ada Mulyadi Kartanegara dalam karyanya "Integrasi IImu: Sebuah Rekonstruksi Holistik" tahun 2005, membahas mengenai pembidangan ilmu pengetahuan berdasarkan rumpunnya dengan penekanan pada pengintegrasian ilmu pengetahuan, yang menegasikan dikotomi ilmu-ilmu agama dan ilmu-ilmu umum. Menurutnya, apa yang telah dilakukan oleh para ilmuan Muslim pada masa klasik dan pertengahan mengenai klasifikasi ilmu pengetahuan, seperti yang dilakukan al-Ghazali, bukan merupakan pendikotomian ilmu pengetahuan umum dan agama atau sebaliknya. Melainkan ia merupakan suatu bentuk pemilahan terhadap disiplin keilmuan berdasarkan cakupan dan kandungannya.

\subsection{Pendidikan Multikultural dan Multikulturalisme di Indonesia}

$\begin{array}{ccr}\text { Perbedaan } & \text { mendasar } & \text { antara } \\ \text { multikulturalisme } & \text { dan } & \text { pendidikan }\end{array}$ multikultural adalah pada tataran teoritis dan pembelajaran. Multikurturalisme telah menjadi bahasan para cendekiawan muslim cukup lama. Tokoh-tokoh cendekiawan muslim Indonesia sepeti Abdurrahman Wahid, Nurcholis Madjid, Ahmad Syafii Maarif, adalah sebagian dari tokoh muslim yang menyerukan dan menyuarakan pentingnya Islam sebagai pemberi solusi dalam semua kebuntuan konsepsi keberagaman, hubungan agama dan negara era modern. Dalam karya tulisnya Qodir menyatakan bahwa ketiga tokoh tersebut menjadi contoh dalam hal keislaman, kemanusiaan, keindonesiaan dan budaya:

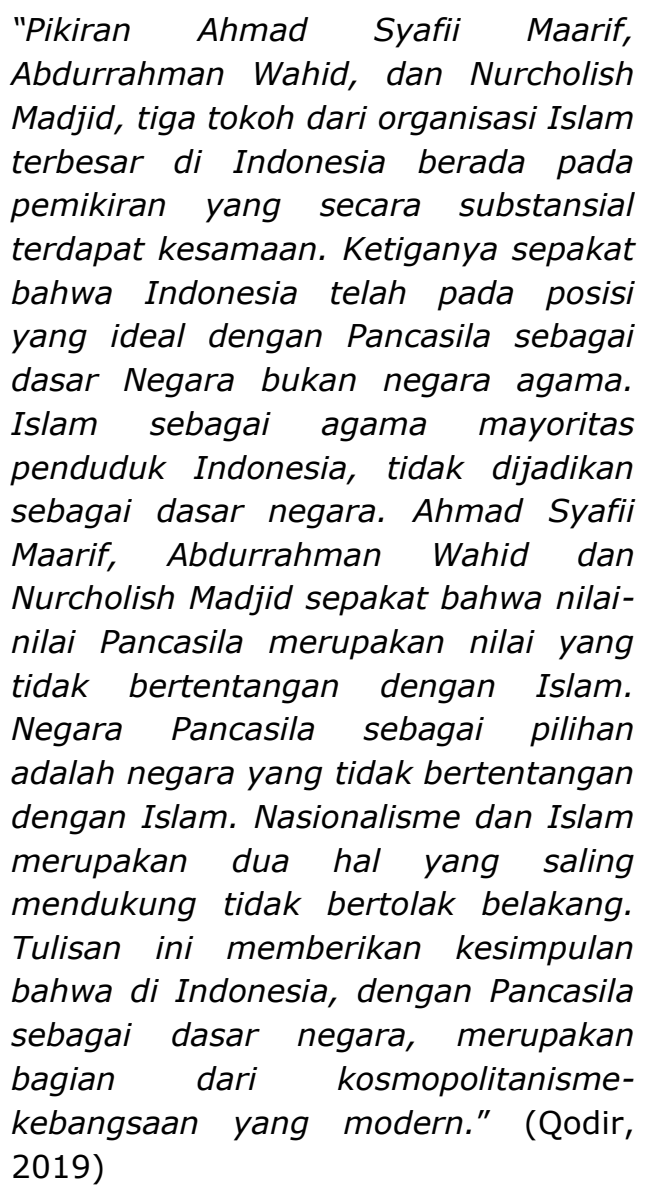

Semua pemikiran ketiga tokoh tersebut pada umumnya dikaitkan dengan pluralism dan atau multikulturalisme. Sedangkan dalam proses pendidikan multikultural, pemikiran ketiga tokoh di atas seringkali 
dijadikan tolok ukur dalam memahami praktek multikulturalisme di Indonesia.

Adapun pendidikan multikulturalisme memiliki sejarah yang cukup panjang sebagai tindak lanjut dari adanya gerakan pencegahan rasisme. Pendidikan multikultural adalah cabang baru dari teori dan praktik pedagogis. Penampilannya dianggap terkait dengan periode transformasi sosial dan budaya yang kompleks di AS selama 1960-an-1970-an. Namun, J. Banks, seorang sarjana Amerika, membuktikan bahwa pendidikan multikultural terkait erat dengan gerakan Afrika-Amerika pada abad ke 19-20. Adapun implementasi pendidikan multikultural ke dalam praktik tergantung pada pelatihan profesional berkualitas tinggi dari seorang pedagog yang dapat bekerja dalam konteks masyarakat multikultural (Sultanova, 2016).

\subsection{Moderasi Islam dan Moderat Beragama}

Moderat dapat dipahami sebagai lawan dari radikal. Istilah moderat mengacu kepada pemahaman bahwa semua agama mengajarkan pentingnya toleransi, penyeimbangan dan seterusnya. Dalam agama Islam istilah moderat lebih dikenal dengan istilah wasatiyah. Secara umum tujuan moderat adalah memerangi paham radikalisme, ektremisme, intoleran dan paham negative lainnya.

Haedar menjelaskan bahwa kata moderasi berasal dari Bahasa Latin moderâtio, yang berarti kesedangan (tidak kelebihan dan tidak kekurangan). Kata itu juga berarti penguasaan diri (dari sikap sangat kelebihan dan kekurangan). Dalam bahasa Inggris, kata moderation sering digunakan dalam pengertian average (ratarata), core (inti), standard (baku), atau non-aligned (tidak berpihak). Secara umum, moderat berarti mengedepankan keseimbangan dalam hal keyakinan, moral, dan watak, baik ketika memperlakukan orang lain sebagai individu, maupun ketika berhadapan dengan institusi negara. Tambah Haedar, Islam Indonesia memiliki karakter moderat sebagaimana Islam Melayu di kawasan Asia Tenggara, meski sering dikategorikan "periferal" dan "sinkretis" dari segi ajaran, tetapi tegar sebagai Islam yang damai, ramah, dan toleran (Nashir, 2019).

$\begin{array}{lllr}\text { Dalam } & \text { kehidupan } & \text { beragama } & \text { atau } \\ \text { keagamaan } & \text { pandangan } & \text { moderat } & \text { atau } \\ \text { moderasi, } & \text { menurut } & \text { Haedar } & \text { harus }\end{array}$
menempatkan agama sebagai ajaran yang positif dan memiliki fungsi penting dalam kehidupan keindoneiaan. Hal itu didasarkan pada argumen kuat bahwa Indonesia tidak dapat lepas dari agama yang membentuk karakter orang Indonesia menjadi masyarakat relijius.

Dalam istilah Gusdur, Agama Islam harus dipahami secara inklusif. Artinya terbuka dalam memberikan penghormatan kepada praktik adama orang lain yang berbeda dengan Islam. Moderasi beragama merupakan kunci terciptanya toleransi dan kerukunan antar semua golongan. Tidak membedakan minoritas dan mayoritas, melainkan menjalin keharmonisan dalam kehidupan dengan menyeimbangkan antara perbedaan dan persamaan secara wajar.

Sejarah Islam telah menunjukkan bahwa masa Rasulullah Saw. Telah mempraktekkan adanya moderasi beragama. Pada masa awal-awal kehadiran Islam tercermin keberagaman tersebut dengan membebaskan pembodohan atas perbudakan menjadi peyeimbangan persamaan derajat kemanusiaan. Dalam perkembangannya, moderasi Islam berkembang dalam berbagai disiplin ilmu. Pertama, moderasi akidah islam. Dimaksudkan sebagai munculnya beragama aliran dalam Islam baik al asy'ariyah yang moderat, muktazilah yang rasional, hanabilah yang tekstual. Kedua, moderasi hukum islam. Tujuan pemberlakuan hokum adalah untuk tercapainya kemaslahatan umat manusia. Sebuah hokum senantiasa lahir dari pergumulan social kemasyarakat yang dinamis. Ketiga, moderasi penafsiran. Kitab suci al Qur'an yang dikaji dan ditafsiri oleh para ulama tafsir memberikan pemahaman komprehensif terkait kandungan kitab suci. Beragama produk tafsir yang telah dilahirkan para mufassir dapat memberikan suimbangsih terhadap persoalan-persoalan kemanusiaan. Misalnya, tafsir maqhasid merupakan penafsiran yang dilakukan dengan cara menggali makna tersirat dari lafadz al Qur'an dengan mempertimbangkan tujuan yang terkandung di dalamnya. Keempat, moderasi pemikiran Islam (Sutrisno, 2019). 


\subsection{Kurikulum Keagamaan di Perguruan Tinggi}

Menurut Hamid Hasan dalam keseluruhan proses pembangan kurikulum dengan pengembangan empat dimensi kurikulum, yaitu: pertama, Kurikulum dalam dimensi ide, berkenaan dengan landasan filosofis dan teoritis kurikulum. Artinya aspek filosofis ini terlihat apakah kurikulum dikembangkan untuk menjawab kebutuhan masyarakat dalam pengembangan disiplin ilmu, teknologi, agama, permasalahan sosial buadaya, ekonomi, kebangsaan dan lain-lain. Kedua, Kurikulum dalam dimensi dokemen, maka kurikulum berisikan komponen; tujuan conten, proses dan assesmen. Ketiga, Kurikulum dalam dimensi proses adalah implementasi dari apa yang direncanakan dalam dimensi dokumen. Keempat, Kurikulum dalam dimensi hasil adalah apa yang dimiliki oleh peserta didik/mahasiswa.

Pengembangan dan Implementasi pendidikan multikultur pada pendidikan tinggi, dapat dikemas ke dalam muatan kurikulum seperti pendidikan kewargaanegaraan, prinsip-prinsip pendidikan multikultural, landasan pendidikan mutikultural dan pendidikan keberagamaan dilakukan serta dapat dilakukan melalui hidden kurikulum atau sentuhan dalam konteks pembinaan akhlak mulia, memiliki intensitas untuk membina dan mengembangkan kerukunan hidup antar umat beragama. Olehnya itu, pendidikan multikultural ini bisa dimasukkan sebagai kurikulum perguruan tinggi ke dalam berbagai mata kuliah. Walaupun dalam format kurikulum pendidikan tinggi belum menjadi suatu kurikulum dengan sejumlah mata kuliahnya yang berdiri sendiri. Beberapa kompetensi dasar yang bisa dikembangkan dalam pendidikan multikultural antara lain:

Pertama; menjadi warga negara yang menerima dan menghargai perbedaan etnik, agama, bahasa dan budaya dalam struktur masyarakat. Kedua; menjadi warga negara yang bisa bekerjasama multi etnik, multi kultur, dan multi religi dalam konteks pengembangan ekonomi dan kekuatan bangsa. Ketiga; menjadi warga negara yang mampu menghormati hak-hak individu warga negara tanpa membedakan latar belakang etnik, agama, bahasa dan budaya dalam semua sektor sosial, pendidikan, ekonomi, politik dan lainnya. Bahkan mampu memelihara bahasa dan mengembangkan budaya. Keempat; menjadi warga negara yang memberi peluang pada semua warga negara untuk terwakili gagasan dan aspirasinya dalam lembaga-lembaga pemerintahan, baik legislatif maupun eksekutif, dan kelima; menjadi warga negara yang mampu mengembangkan sikap adil dan mengembangkan rasa keadilan terhadap semua warga tanpa membedakan latar belakang etnik, agama, bahasa dan budaya.

Kurikulum akan terus berkembang mengikuti perkembangan jaman dan masyarakat. Artinya, pengembangan sebuah kurikulum dilakukan secara dinamis dan berkesinambungan menuju penyempurnaan. Menurut Idi dalam Mansur, prinsip pengembangan kurikulum setidaknya mengikuti kaidah; relevansi, efektifitas, efisiensi, kesinambungan, fleksibilita, berorientasi pada tujuan dan prinsip model pengembangan.

\subsection{Pendidikan Moderat Beragama}

Pendidikan moderat beragama dapat dikatakan sebagai proses pendidikan agama (Islam) yang bertoleran. Pendidik dan peserta didik diharapakan saling memahami akan pentingnya menghindarkan diri dari paradigma, sikap atau perilaku yang intoleran atau disharmoni dalam sosial keagamaan di Indonesia. Dalam internal muslim misalnya, masalah intoleransi beda mazhab masih sangat tinggi. Penganut mazhab minoritas diklaim sesat dan kafir. Sebagai contoh sikap moderat, MUI tingkat pusat tidak pernah melarang warga dan ajaran Syi'ah di Indonesia. Sikap yang di pilih MUI adalah memberikan himbauan agar umat Islam berhati-hati terhadap kemungkinan beredarnya kelompok Syi'ah yang ekstrim. Walaupun ada MUI tingkat daerah yang menyesatkan syi'ah, seperti MUI Jawa Timur dan Sulawesi Selatan, yang kemudian dapat penolakan dari organisasi NU dan Muhammadiyah, karena bisa memicu konflik horizontal antar umat Islam (Rahmat, 2018).

Kedewasaan pemeluk agama satu dengan agama lain harus ditampakkan dalam kehidupan sehari-hari secara harmoni. Kesadaran tersebut tidak serta merta muncul 
dari adanya faktor keteladan para tokoh agama, melainkan perlu ditanamkan sejak dini dalam lembaga-lembaga pendidikan formal dan non formal, khususnya di lembaga pendidikan tinggi. Menurut Rahmat, pendidikan agama islam yang moderat, damai, dan toleran di pengaruhi faktor keterbukaan pendidik (dosen), faktor substansi materi yang inklusif dan metode perkuliahan yang dialogis argumentatif (Rahmat, 2018).

Kementerian Agama RI, menetapkan 10 nominator dosen PAI se Indonesia yang paling produktif dan moderat tingkat nasional. Tiga diantaranya adalah Prof. Dr. Abas Asyafah berlatar belakang Nu dengan corak berpikir religious inklusif, Prof. Dr. endis Firdaus berlatar belakang Persis dengan corak berpikir regius inklusif namun cenderung liberal, dan Dr. Munawar Rahmat berlatar belakang Muhammadiyah corak berpikir religious inklusif. Ketiganya memberikan substansi materi PAI yang tujuannya membangun sikap dan perilaku yang damai, moderat dan toleran. Adapun materi PAI tersebut bertemakan; (1) makna beragama Islam adalah tunduk patuh secara mutlak kepada Allah dan Rasul-Nya; (2) Misi atau tujuan utama agama Islam adalah menyempurnakan Akhlak mulia, dan (3) mengetahui kesempurnaan keimanan, ketakwaan, peribadatan, akhlak mulia dan ilmu Rasulullah Saw. (4) Keragaman mazhab dan keyakinan religious dalam Islam merupakan sebuah keniscayaan. Dengan demikian, pendidikan moderat beragama, tidak hanya dimaksudkan sebagai pintu utama para pendidik dalam menguraikan materi PAI yang rahmatan lil 'alamin, melainkan lebih dari itu mengupayakan terbentuknya paradigm peserta didik yang mampu bersikap moderat, bertoleran dan hidup secara harmoni dengan pemeluk agama lain. Sehingga perwujudan kerukunan umat beragama di Indonesia semakin kuat dan kokoh.

\section{Kesimpulan}

Pengembangan dan implementasi pendidikan multikultur pada pendidikan tinggi, dapat dikemas ke dalam muatan kurikulum seperti pendidikan kewargaanegaraan, prinsip pendidikan multikultural, landasan pendidikan mutikultural dan pendidikan keberagamaan dilakukan serta dapat dilakukan melalui hidden kurikulum atau sentuhan dalam konteks pembinaan akhlak mulia, memiliki intensitas untuk membina dan mengembangkan kerukunan hidup antar umat beragama. Olehnya itu, pendidikan multikultural ini bisa dimasukkan sebagai kurikulum perguruan tinggi ke dalam berbagai mata kuliah. Walaupun dalam format kurikulum pendidikan tinggi belum menjadi suatu kurikulum dengan sejumlah mata kuliahnya yang berdiri sendiri.

\section{Daftar Pustaka}

Ahmad, \& Ansori. (2015). Radikalisme di Indonesia : Antnara historisitas dan antropisitas. Kalam, 253-268.

Damrizal. (2016). "Kebebasan Beragama Dalam Perspektif Abdurrahman Wahid." Manthiq 1(2), (2016).

Haidar, B. (2017). Islam Tuhan, Islam Manusia: Agama dan Spiritualitas di Zaman Kacau. Bandung: Mizan.

Hidayat, M. (2014). "Pendekatan IntegratifInterkonektif: Tinjauan Paradigmatik dan Implementatif dalam Pembelajaran Pendidikan Agama Islam." Ta'dib: Journal of Islamic Education (Jurnal Pendidikan Islam), (19) 2, 276-290.

Izudin, A. (2017). “Penggunaan Paradigma Integrasi-Interkoneksi dalam Proses Pembelajaran di Program Pascasarjana UIN Sunan kalijaga Yogyakarta," Jurnal Afkaruna, 13(1), 103-114.

Machali. (2015). "Pendekatan IntegrasiInterkoneksi dalam Kajian Manajemen dan Kebijakan Pendidikan Islam." El Tarbawi 8(1), 32-53.

Kapraja, S. (2016). "Pendidikan Multikultural dalam Pengembangan Kurikulum 
Perguruan Tinggi (sebuah Kajian

Kurikulum)." Biosel (Biology Science and Education): Jurnal Penelitian Sains dan Pendidikan 5(1), 38-45.

Knitter, \& Paul, F. (2008). Satu Bumi Banyak Agama : Dialog Multi_Agaman dan Tanggung Jawab Global. Jakarta: Gunung Mulia.

Musa, A.M. (2014). Membumikan Islam Nusantara; Respon Islam terhadap Isu-Isu Aktual. Jakarta: Serambi.

Nasaruddin, U. (2014). Islam Fungsional : Revitalisasi dan Reaktualisasi Nilainilai Keislaman. Jakarta: Quanta.

Sobron, Titik, \& S, M. (2020). Studi Pengaruh Daring Learning Terhadap Hasil Belajar Matematika Kelas IV. Jurnal Inovasi Penelitian, 256-276.

Sultanova, L. (2016). "Origin and Development of Multicultural Education in the USA." Comparative Professional Pedagogy, (6)2, 2016: 49-53.

Sutrisno, E. (2019). "Aktualisasi Moderasi Beragama Di Lembaga Pendidikan". Jurnal Bimas Islam, 12(2), 325-331.

Qodir, Z. (2019). "Keislaman, Kemanusiaan, Keindonesiaan dan Budaya: Pemikiran Ahmad Syafii Maarif, Nurcholish Madjid dan Abdurrahman Wahid." Afkaruna: Indonesian Interdisciplinary Journal of Islamic Studies (15)2, 226253.

Wahid, A. (2006). Islamku Islam Anda dan Islam Kita. Jakarta: Wahid Institute 